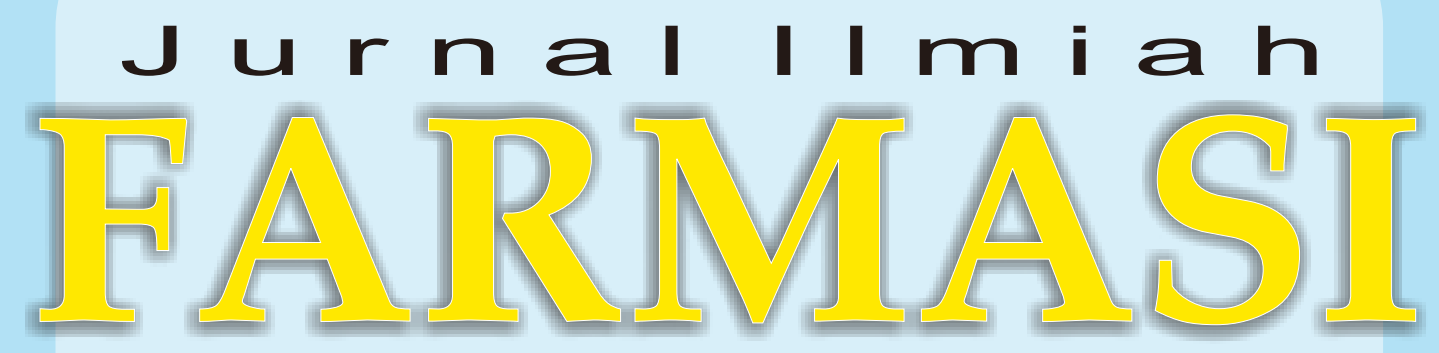

(Scientific Journal of Pharmacy) 
JURNAL ILMIAH FARMASI

(SCIENTIFIC JOURNAL OF PHARMACY)

PIMPINAN UMUM/ PENANGGUNG JAWAB

Dekan Fakultas Matematika dan Ilmu Pengetahuan Alam

Universitas Islam Indonesia

WAKIL PIMPINAN UMUM/ WAKIL PENANGGUNG JAWAB

Ketua Jurusan Farmasi FMIPA UII

\section{MITRA BESTARI}

1. Prof. Dr. Wiryatun Lestariana, Apt

2. Prof. Dr. Zullies Ikawati, Apt

3. Prof. Dr. Sudibyo Martono, Apt

4. Dr. Tedjo Yuwono, Apt

5. Prof. Dr. Dachriyanus, Apt

6. Prof. dr. Iwan Dwiprahasto, MMedSc, PhD

7. Prof. Dr. Lukman Hakim M.Sc., Apt

8. Prof. Dr. Achmad Fudholi, DEA, Apt

9. Prof. Dr. Ibnu Gholib Gandjar, DEA., Apt

\begin{tabular}{ll} 
& \multicolumn{1}{c}{ DEWAN EDITOR } \\
Ketua & : Saepudin, M.Si., Apt \\
Sekretaris & : Rochmy Istikharah, M.Sc., Apt. \\
Anggota & : Vitarani Dwi Ananda Ningrum, M.Si., Apt \\
& Okti R. Mafruhah, MSc., Apt \\
& Dimas Adhi Pradana, MSc., Apt. \\
& Fithria DA. Suryanegara, MSc., Apt. \\
& Ari Wibowo, S.Farm., Apt \\
& Arba Pramudita Ramadani, MSc., Apt. \\
& Oktavia Indrati, S.Farm., Apt.
\end{tabular}

Penerbit

Jurusan Farmasi Fakultas Matematika dan IImu Pengetahuan Alam Universitas Islam Indonesia

Alamat Penerbit Jurusan Farmasi FMIPA UII

Jl. Kaliurang Km. 14,4 Yogyakarta 55584

Telp. (0274) 896439 ext. 3047

Email: jif@uii.ac.id 


\title{
PEMANFAATAN ZAT WARNA WORTEL (Daucus carota Linn) DALAM PEMBUATAN PEWARNA BIBIR BENTUK BATANG (LIPSTIK)
}

\author{
Yuni Andriani*, Sri Soeryati. H.I Hj, Dolih Gozali \\ Department of Pharmaceutical, Faculty of Pharmacy, Padjadjaran University, Indonesia \\ *e-mail: yuni_fmasi@yahoo.com
}

\begin{abstract}
The utilization of natural colorant in cosmetic dosage form, especially the colorant of carrot (Daucus carota Linn) in the preparation of lipstick colorant have been carried out. It can be known from the research that the extract colorant of carrot had an orange color and stable during storage times. Lipstick formulation with various concentration of the root colorant $(20,30$, and $40 \%)$, produced lipstick that had good physical stability during storage times, and it had orange up to reddish orange, safe to be used, and the formula especially with the carrot colorant of $30 \%$ was more favorable.
\end{abstract}

Keywords: cosmetics, lipstick, natural colorant, $\beta$-carotenoid, carrot 